\title{
IMPLEMENTASI PANCASILA SEBAGAI DASAR NEGARA
}

\author{
Puji Ayu Handayani \& Dinie Anggraeni Dewi \\ Universitas Pendidikan Indonesia \\ pujiayuhandayanii85@gmail.com
}

\begin{abstract}
Abstrak
Tulisan ini bertujuan untuk lebih mengetahui dan memahami tentang pancasila dan nilai nilai yang terkandung dalam pancasila itu sendiri, dan pentingnya pancasila bagi suatu negara. Penelitian ini menggunakan metode kualitatif dan pembahasan secara deskriptif, yaitu teori yang menjadi bahan pembahasannya diperoleh dari hasil studi kepustakaan dengan berbagai macam sumber yang ada dari jurnal, artikel, buku yang memiliki kedalaman dari para ahli. Dengan pentingnya pancasila sebagai suatu negara maka penulis tertarik untuk menganalisi kembali implementasi pancasila sebagai dasar negara. Dengan demikian, implementasi pancasila sangat penting bagi suatu negara.
\end{abstract}

Kata kunci: Pancasila, Dasar Negara, Kedudukan

\begin{abstract}
This paper aims to better know and understand about Pancasila and the values contained in Pancasila itself, and the importance of Pancasila for a country. This research uses qualitative methods and descriptive discussion, namely the theory that becomes the discussion material obtained from the results of literature studies with a variety of sources available from journals, articles, books that have depth from experts. With the importance of Pancasila as a country, the authors are interested in re-analyzing the implementation of Pancasila as the basis of the state. Thus, the implementation of Pancasila is very important for a country.
\end{abstract}

Key words: Pancasila, State Basis, Position

\section{PENDAHULUAN}

Pancasila adalah dasar negara dan ideologi nasional, hal ini membawa konsekuensi logis bahwa nilai nilai pancasila dijadikan sebagai landasan pokok, dan landasan fundamental bagi penyelenggaraan negara Indonesia. Pancasila berisi lima sila yang pada hakikatnya berisi lima nilai dasar yang fundamental. Nilai nilai dasar dari pancasila tersebut adalah nilai Ketuhanan Yang Maha Esa, nilai Kemanusiaan Yang Adil dan Beradab, nilai Persatuan Indonesia, nilai Kerakyatan yang dipimpin oleh hikmat kebijaksanaan dalan permusyawaratan/perwakilan, dan nilai Keadilan sosial bagi seluruh rakyat indonesia. Dengan pernyataan secara singkat bahwa nilai dasar Pancasila adalah nilai ketuhanan, nilai kemanusiaan, nilai persatuan, nilai kerakyatan, dan nilai keadilan. Pancasila juga dapat di artikan sebagai ideologi dari negara Indonesia atau sering di sebut rumusan kehidupan berbangsa dan bernegara.

Penerapan pancasila sebagai dasar negara memberikan pengertian bahwa negara indonesia merupakan negara pancasila. Negara pancasila merupakan suatu negara yang didirikan dan dipertahankan serta dikembangkan dengan tujuan untuk melindungi dan mengembangkan martabat dan hak hak semua warga negara indonesia, agar semua rakyat dapat hidup layak sebagai manusia, menggembangkan dirinya dan mewujudkan kesejahteraannya sebaik mungkin, memajukan kesejahteraan umum, dan mencerdaskan kehidupan bangsa (keadilan sosial).

Implementasi pancasila dapat menjadi media dan sarana interaksi yang efektif, guna merumuskan konsep sosialisasi dan implementasi pancasila dalam kehidupan berbangsa dan bernegara. Sasaran dan metodologi 
menjadi begitu penting mengingat realisasi dan dinamika kehidupan yang ada saat ini sangat diwarnai oleh berkembangnya nilai nilai demokrasi dalam proses demokratisasi yang terus berkelanjutakan.

Pada saat era reformasi sampai sekarang perubahan terjadi serta terus menerus dengan begitu cepat dan menghasilkan dampak positif dan negatif serta sangat berpengaruh dalam sistem pemerintahan negara indonesia.

\section{METODE PENELITIAN}

Artikel ini menggunakan pendekatan deskriptif analitis. Pendekatan ini dipilih karena merupakan metode paling tepat untuk menggambarkan, mendeskripsikan, dan menganalisis Pancasila sebagai dasar negara Indonesia. Pengumpulan data melalui observasi, wawancara, dan dokumentasi.

\section{HASIL PENELITIAN DAN PEMBAHASAN Hasil Penelitian}

Pancasila adalah dasar negara dan hukum utama di Indonesia. Pancasila terdiri dari dua jenis kata yaitu "pantja" dan "sila". Pantja berarti lima, dan sila berarti asas atau sendi. Pancasila berisi lima asas yang meliputi aspek, ketuhanan, kemanusiaan, persatuan, kerakyatan dan keadilan sosial.

Teks Pancasila Menurut piagam Jakarta:
1. Ketuhanan
dengan
kewajiban
menjalankan syariat Islam bagi pemeluk-pemeluknya.

2. Kemanusiaan yang adil dan beradab.

3. Persatuan Indonesia.

4. Kerakyatan yang di pimpin oleh hikmat kebijaksaan dalam permusyawaratan perwakilan.

5. Keadilan sosial bagi seluruh rakyat Indonesia.

Menurut UUD 1945 :

1. Ketuhanan yang maha esa.
2. Kemanusiaan yang adil dan beradab.

3. Persatuan Indonesia.

4. Kerakyatan yang di pimpin oleh hikmat kebijaksaan dalam permusyawaratan perwakilan.

5. Keadilan sosial bagi seluruh rakyat Indonesia.

Dasar negara merupakan landasan dalam suatu negara guna menjalankan dan melaksanakan kehidupan masyarakat di berbagai bidang. Dasar Negara juga mempunyai makna sebagai pedoman dasar dan cita cita bangsa dalam mengatur kehidupan ketatanegaraan yang mencakup segala kehidupan bermasyarakat.

Negara Indonesia memiliki dasar negara yaitu Pancasila. Merupakan hasil gagasan dari Ir. Soekarno pada tanggal 1 Juni 1945. Pancasila sendiri memiliki makna sangat dalam bagi bangsa Indonesia, selain sebagai cita cita bangsa, pancasila juga berfungsi sebagai pemersatu antar umat bangsa dan sebagai pedoman rakyatnya dalam menjalankan aktivitas sehari hari diberbagai bidang.

Secara singkatnya, dasar negara merupakan landasan dalam suatu negara guna menjalankan dan melaksanakan kehidupan bermasyarakat di berbagai bidang dasar negara juga bermakna sebagai pedoman dasar dan cita cita bangsa dalam mengatur kehidupan ketatanegaraan yang mencakup segala kehidupan bermasyarakat.

\section{Pembahasan}

Pancasila mempunyai arti lima dasar atau 5 asas yaitu nama dari dasar negara kirta, negara republik indonesia. Istilah pancasila ini, sudah dikenal sejak zaman majapatih pada abad XIV yang terdapat dalam buku "Nagara Kertagama" karangan Mpu Tantular, dalam buku sutasoma tersebut, selain mempunyai arti "berbatu sendi yang lima” (dari bahasa sansekerta) pancasila juga mempunyai arti 
"pelaksanaan kesusilaan yang lima", diantaranya, yaitu sebagai berikut :

1. Tidak boleh melakukan kekerasan

2. Tidak boleh mencuri

3. Tidak boleh berjiwa dengki

4. Tidak boleh berbohong,

5. Tidak boleh mabuk mabukan dan meminum minuman keras / obat obatan terlarang.

Pancasila merupakan sebuah landasan dan pedoman utama bagi Pancasila merupakan sebuah landasan dan pedoman utama bagi masyarakat Indonesia dalam melaksanakan segala kegiatan bermasyarakat, berbangsa dan bernegara (Nurgiansah, 2021). Pancasila juga menjadi sumber dari segala sumber hukum di Indonesia yang memiliki nilai nilai khas Negara Kesatuan Republik Indonesia.

Pancasila Sebagai Dasar negara artinya adalah Sebagai Pondasi negara dan Pegangan Bangsa yang kuat sehingga bangsa indonesia memiliki Ideologi sendiri dan mampu berdiri menjadi bangsa yang kokoh tanpa dipengaruhi oleh bangsa bangsa lainnya. Makna Makna Pancasila diantaranya sebagai berikut, diantaranya yaitu :

Sebagai dasar negara: Pancasila merupakan sebuah landasan dan pedoman utama bagi masyarakat Indonesia dalam melaksanakan segala kegiatan bermasyarakat, berbangsa dan bernegara. Pancasila juga menjadi sumber dari segala sumber hukum di Indonesia yang memiliki nilai nilai khas Negara Kesatuan Republik Indonesia.

Sebagai pandangan hidup: Pancasila merupakan sebuah landasan fundamental sebagai suatu petunjuk yang digunakan masyarakat Indonesia dalam melaksanakan berbagai bidang aktifitas dengan mencakup nilai- nilai moral, religius dan kebudayaan untuk menyelesaikan segala permasalahan secara tepat.

Landasan Hukum Pancasila; Sidang
PPKI 18 Agustus 1945 Sidang PPKI pertama memabahas tentang pengesahan UUD NRI 1945. Tepatnya ada di dalam pembukaan UUD NRI 1945 terdapat tulisan pancasila dalam alinea ke 4.Berita Republik Indonesia No. 7 Tahun 1946. Pancasila dalam UUD NRI 1945 disebutkan pada berita Republik Indonesia tahun II No. 7 bertanggal 15 Februari 1946 disertai batang tubuh UUD NRI 1945. Instruksi Presiden (Inpres) No. 12 Tahun 1968. Dalam Inpres tercantum pancasila yang sah sesuai dengan pancasila di alinea ke 4 pembukaan UUD NRI 1945. Hal ini disampaikan dalam inpres No. 12 Tahun 1968 bertanggal 13 April 1968. Ketetapan MPR No. XVIII/MPR/1998 Ketetapan MPR No. XVIII/MPR/1998 merupakan penegasan tentang kedudukan pancasila sebagai dasar negara Indonesia.

Setiap negara pasti mempunyai dasar negara. Dasar negara merupakan fundamen atau pondasi dari bangunan negara. Kuatnya fundamen sebuah negara akan menguatkan berdirinya negara itu. Sedangkan kerapuhan fundamen suatu negara yaitu disebabkan oleh lemahnya negara tersebut. Sebagai dasar negara indonesia, pancasila sering disebut sebagai dasar falsafah negara (filosofische gronslad dari negara), dan staats fundamentele norm, weltanschauug dapat diartikan sebagai ideologi negara (staatsidee). Negara indonesia ini, dalam pengelolaan atau pengaturan kehidupan bernegara sangat dilandasi oleh filsafat atau ideologi pancasila. Fundamen suatu negara harus tetap kuat dan kokoh serta tidak memungkinkan untuk diubah. Mengubah fundamen, dasar, atau ideologi berarti mengubah eksistensi dan sifat suatu negara. Keutuhan suatu negara dan bangsa bertolak dari sudut kuat atau lemahnya bangsa itu berpegang kepada dasar negaranya.

Kedudukan pancasila sebagai dasar negara berarti pancasaila sebagai dasar 
dari suatu penyelenggaraan kehidupan bernegara bagi negara indonesia. Kedudukan pancasila sebagai dasar negara tersebut sesuai dengan yang tersusun dalam UUD 1945 alinea ke 4. Dengan kedudukan yang istimewa tersebut, maka dalam proses penyelenggaraan kehidupan bernegara memiliki fungsi yang kuat juga. Pasal pasal dalam UUD 1945 menggariskan ketentuan ketentuan yang menunjukkan fungsi pancasila dalam proses pelaksanaan kehidupan bernegara. Dibawah ini dikemukakan ketentuan ketentuan yang menunjukan fungsi dari masing masing sila dalam proses pelaksanaan kehidupan bernegara.

Ketentuan yang menunjukan fungsi dari sila Ketuhanan Yang Maha Esa, yaitu: kehidupan bernegara bagi bangsa indonesia berdasarkan pada ketuhanan yang maha esa. Negara menjamin setiap warganya untuk memeluk agama dan beribadah sesuai agamanya masing masing, serta memberikan toleransi dari setiap umat beragama. Dan negara juga memberikan kebabasan untuk setiap agama yang dianut oleh warga negaranya.

Selanjutnya, ketentuan yang menunjukkan fungsi dari sila Kemanusiaan Yang Adil dan Beradab, yaitu : pengakuan oleh negara terhadap hak bagi setiap bangsa untuk menentukan nasibnya sendiri, negara mengkehendaki agar warga negara indonesia tidak melakukan tindakan yang sewenangnya kepada sesama manusia sebagai manisfestasi sifat bangsa yang berbudaya tinggi. Jaminan kedudukan yang sama dalam hukum dan pemerintahan serta berkewajiban untuk menjunjung tinggi hukum dan pemerintahan yang ada bagi setiap warga negaranya.

Ketentuan yang menunjukkan fungsi dari sila ke 3, atau Persatuan Indonesia, yaitu : perlindungan negara terhadap segenap bangsa indonesia dan seluruh tumpah darah indonesia, memajukan kesejahteraan umum, mencerdaskan kehidupan bangsa, dan ikut melaksanakan ketretiban dunia yangberdasarkan kemerdekaan, perdamaian abadi dan keadilan sosial, negara mengatasi segala paham golongan dan segala paham perseorangan, serta pengakuan negara terhadap kebhineka tunggal ika-an dari bangsa indonesia dan neagaranya.

Ketentuan yang menunjukkan fungsi dari sila ke 4, atau Kerakyatan Yang dipimpin oleh Hikmat Kebijaksanaan dalam Permusyawaratan Perwakilan, yaitu : penerapan kedaulatan dalam bernegara yang berada di tangan rakyat dan dilakukan oleh MPR, penerapan asas musyawarah untuk mufakat dalam pengambilan segala keputusan dalam negara indonesia, dan baru bisa menggunakan pungutan suara terbanyak bila hal tersebut tidak dapat dilakukan dan dilaksanakan. jaminan bahwa setiap warga negara bisa memperoleh keadilan yang sama, sebagai formulasi negara hukum, dan bukan berdasarkan pada kekuasaan, serta penyelenggaraan kehidupanyang didasarkan atas konstitusi dan tidak bersifat absolute.

Terakhir, ada ketentuan yang menunjukkan fungsi dari sila ke 5, atau Keadilan Sosial Bagi Seluruh Rakyat Indonesia, yaitu : negara menghebdaki agar perekonomian indonesia berdasarkan atas asas kekeluargaan, penguasaan cabang cabang produksi yang penting bagi negara serta menguasai hajat hidup orang banyak oleh negara,negara mengkehendaki agar kekayaan alam yang ada dalam indonesia bisa digunakan untuk kemakmuran semua rakyatnya.negara indonesia juga mengkehendaki agar setiap warga negaranya mendapatkan perlakuan yang sangat adil di segala kehidupan, baik itu secara material maupun spiritual. Indonesia juga mengkehendaki agar warga negaranya memperoleh pendidikan dan pengajaran secara maksimal dan 
menyeluruh.

Negara indonesia juga mengusahakan dan menyelenggrakan suatu sistem pengajaran nasional yang pelaksanaannya diatur oleh undang undang, bahwa pemerataan pendidikan agar dapat diperoleh oleh semua warga negara, dan negara berusaha membentuk warga negara indonesia yang seutuhnya dab kompeten, hingga bisa bersaing dengan negara negara lain. Sebagai dasar negara, Pancasila diuji kembali ketahanannya dalam era reformasi sekarang ini. Pada bulan juni 1945, tepatnya 64 tahun yang lalu, lahirnya konsepsi kenegaraan yang sangat bersejarah bagi negara indonesia, yaitu ditandai dengan lahirnya pancasila. Sebagai falsafah negara tentunya pancasila merupakan karunia terbesarbagi segenap bangsa dan negara indonesia.

Pancasila sudah ada dalam segala bentuk kehidupan rakyat indonesia. Pancasila lahir pada tanggal 1 juni 1945, dan ditetapkan pada tanggal

18 agustus 1945, bersamaan dengan UUD 1945. Bunyi dan ucapan pancasila yang benar berdasarkan inpres Nomor 12 tahun 1968, diantaranya yaitu :

1. Ketuhanan Yang Maha Esa

2. Kemanusiaan Yang Adil dan Beradab

3. Persatuan Indonesia

4. Kerakyatan Yang dipimpin oleh Hikmat

Kebijaksanaan dalam Permusyawarat Perwakilan

5. Keadilan Sosial Bagi Seluruh Rakyat Indonesia.

Dalam sejarah indonesia, telah mencatat bahwa diantara tokoh tokoh perumus pancasila itu diantaranya adalah Mr. Mohammad Yamin, Prof. Mr. Soepomo, dan Ir. Soekarno. Maka, dapat dikemukakan mengapa pancasila itu sakti dan selalu dapat bertahan dari guncangan kisruh politik di negara indonesia ini, yaitu yang pertama adalah karena secara intrinsik dalam pancasila itu mengandung toleransi, dan barang siapa yang menentang pancasila, maka ia menentang toleransi.

Karena itu, pancasila merupakan wadah yang cukup fleksibel, dimana dapat meambung atau mencangkup paham paham positif yang dianut oleh negara indonesia. Selanjutnya, karena sila sila dalam pancasila itu terdiri dari nilai nilai serta norma norma yang positif dan sesuai dengan pandangan hidup bangsa negara indonesia, sedangkan nilai dan norma yang bertentangan dengan pancasila, pasti akan di tolak. Contohnya seperti atheisme. Karena, pancasila itu benar dan tidak bertentangan dengan keyakinan serta agamanya.

Pancasila sebagai dasar negara didapat dari pembukaan uud 1945 alinea ke 4 dan tertuang dalam memorandum DPR-GR 9 juni 1966 yang menandakan pancasila sebagai pandangan hidup yang telah didapatkan dan dimurnikan oleh ppki, atas nama rakyat indonesia menjadi dasar negara republik indonesia. Memorandum DPR-GR itu disahkan pula oleh MPRS dengan ketetapan No. XX/MPRS/1966. ketetapan MPR No.V/MPR/1978 yang menegaskan kedudukan pancasila sebagai sumber dari segala sumber hukum atau sumbeer dari tertib hukum di indonesia.

Dasar pancasila yang pertama dan utama, yaitu sebagai dasar negara indonesia. Penerapan pancasila sebagai dasar negara memberikan pengertian bahwa negara indonesia itu merupakan negara pancasila. Hal itu mengandung arti bahwa negara harus tunduk padanya, membela serta melaksanakan seluruh perundang undangan. Kirdi Dipoyudo (1979:30) menjelaskan negara pancasila adalah suatu negara yang didirikan, dipertahankan, dan dikembangkan dengan tujuan untuk melindungi dan mengembangkan martabat serta hak hak asasi semua warga negara indonesia. Agar 
semua warga negara indonesia dapat hidup dengan layak di indonesia.

Pandangan tersebut melikiskan pancasila secara integral (utuh dan menyeluruh) sehingga menjadikan penopang yang kokoh dan kuat terhadap negara yang didirikan diatasnya, dipertahankan dan dikembangkan dengan tujuan untuk melindungi dan mengembangkan martabat dari hak hak asasi semua warga indonesia ini. Perlindungan dan pengembangan martabat serta hak hak asasi semua warga negara, perlindungan dan pengembangan martabat kemanusiaan itu merupakan kewajiban negara, yakni dengan memandang manusia qua talis, manusia adalah manusia sesuai dengan principium identitasnya.

Dengan demikian maka dapat kita ringkas bahwa pancasila sebagai dasar negara itu, sesungguhnya berisi: Ketuhanan yang maha esa, yang berkemanusiaan yang adil dan beradab, yang berpersatuan indonesia, dan berkerakyatan yang dipimpin oleh hikmad, kebijaksanaan dalam permusyawaratan /peradilan, serta berkeadilan sosial bagi seluruh rakyat indonesia. Kemanusiaan yang adil dan beradab, yang berketuhanan yang maha esa, yang berpersatuan indonesia, yang berkerakyatan yang dipimpin oleh hikmat, kebijaksanaan dalam permusyawaratan/ perwakilan, dan berkeadilan sosial bagi seluruh rakyat indonesia. Persatuan Indonesia, yang berketuhanan yang maha esa, dan berkemanusiaan yang adil dan beradab, berkerakyatan yang dipimpin oleh hikmat kebijaksanaan dalam permusyawaratan /perwakilan, dan berkeadilan sosial bagi seluruh rakyat indonesia. Keadilan sosial bagi seluruh rakyat indonesia, yang berketuhanan yang maha esa, yang berkemanusiaan yang adil dan beradab, yang berpersatuan indonesia, dan berkerakyatanyang dipimpin oleh hikmat kebijaksanaan dalam permusyawaratan /perwakilan. Pancasila berkaitan erat dengan pendidikan pada umumnya, dan secaea khusus pada pendidikan pancasila serta kewarganegaraan (ppkn). (Hidayatillah, 2014).

Mengartikan pancasila kedalam implementasinya, untuk membangun karakter bangsa merupakan upaya merevitalisasi pancasila kedalam bentuk fungsional dalam membentuk karakter bangsa indonesia. Secara kultural dasar pemikiran tentang pancasila dan nilai nilai pancasila muncul pada nilai kebudayaan dan nilai religius yang dimiliki indonesia sendiri. (kaelan,2011:8).

Nilai pancasila merupakan das sollen bagi bangsa indonesia, sehingga seluruh derivasi normatif serta praktis berbasis pada nilai nilai pancasila (Kaelan,2007:10). Integrasi pancasila sebagai sistem filsafat menjadi asas kerohanian bangsa harus dijadikan basis dan inti dalam membangun karakter bangsa yang sinergi dengan pembangunan sistem nasional.

\section{KESIMPULAN}

Pancasila adalah dasar falsafah negara Indonesia, sehingga dapat diambil kesimpulan bahwa Pancasila merupakan dasar falsafah dan ideologi negara yang diharapkan menjadi pandangan hidup bangsa Indonesia sebagai pemersatu, lambang persatuan dan kesatuan serta sebagai pertahanan bangsa dan negara. Pancasila sebagai pandangan hidup Pancasila dianggap memiliki nilai-nilai kehidupan paling baik. Pancasila dijadikan dasar dan motivasi dalam sikap, tingkah laku dan perbuatan dalam hidup bermasyarakat, berbangsa dan bernegara. Semua sila dari Pancasila tidak dapat dilaksanakan secara terpisah-pisah karena Pancasila merupakan satu kesatuan yang utuh dan saling berkaitan.

Ketuhanan Yang Maha Esa Nilai ini mengandung pengakuan atas keberadaan Tuhan sebagai pencipta alam semesta 
beserta isinya. Manusia Indonesia beriman yaitu meyakini adanya Tuhan yang diwujudkan dalam ketaatan kepada Tuhan Yang Maha Esa. Ketaatan iman terlihat dari menjalankan segala perintah dan menjauhi segala larangan Tuhan. Kemanusiaan yang adil dan beradab Nilai ini mengandung rumusan sifat keseluruhan budi manusia Indonesia yaitu mengakui kedudukan manusia sederajat dan sama. Serta mempunyai hak dan kewajiban yang sama sebagai warga negara yang dijamin oleh negara.

Persatuan Indonesia Nilai ini adalah perwujudan paham kebangsaan Indonesia yang mengatasi paham perseorangan, golongan, suku bangsa. Serta mendahulukan persatuan dan kesatuan bangsa sehingga tidak terpecah belah oleh sebab apa pun. Kerakyatan yang dipimpin oleh hikmat kebijaksanaan dalam permusyawaratan perwakilan.

Nilai ini adalah sendi utama demokrasi di Indonesia berdasar atas asas musyawarah dan asas kekeluargaan. Keadilan sosial bagi seluruh rakyat Indonesia Nilai ini adalah salah satu tujuan negara yaitu mewujudkan tata masyarakat Indonesia yang adil dan makmur berdasarkan Pancasila.

Sebagai warga negara indonesia yang baik, hendaknya kita sebagai warga negara indonesia, mempelajarai dan memahami kembali implementasi bahwa pancasila sangat penting bagi kehidupan berbangsa dan bernegara. Dan merupakan dasar negara bagi kita semua.

\section{DAFTAR PUSTAKA}

Adhayanto, O. (2015). Implementasi Nilai-Nilai Pancasila Sebagai Dasar Negara Dalam Pembentukkan Peraturan Perundang- Undangan. Jurnal Ilmu Hukum, 6(2), 166-174.

Ekamisidi(2:4)Pancasila Sebagai Dasar Negara dan Ideologi Nasional jurnal online jakarta 2012 Anonymouse.2017 Dasar negara dan ideologi melalaui paradigma fungsional.

Hidayatillah, Yetti, 2014. Urgensi Eeksistensi Pancasila di Era Globalisasi (Studi Kritis Terhadap Pancasila). Jurnal volume 6 nomor 2Juni 2014.

Kaelan, 2007, Pendidikan Kewarganegaraan, Paradigma, Yogyakarta.

Kaelan, 2011, Fungsi anacila sebagai Paradigma Hukum dalam Meneggakan Konstitusionalitas

Indonesia, Yogyakarta: Sarasehan Nasional Pancasila, Mahkamah Konstitusi RI dan Universitas Gajah Mada, 2-3 Mei 2011

Nurgiansah, T. H. (2021). Pendidikan Pancasila. In Solok: CV Mitra Cendekia Media.

Syam, Mohammad Noor, 2009, Sistem Filsafat Pancasila (Tegak sebagai sistem Kenegaraan Pancasila-UUD Proklamasi 1945, dalam Kongres Pancasila: Pancasila dalam berbagai Presfektif, Jakarta: Setjend MK RI

Widodo, S. (2011). Implementasi Bela Negara Untuk Mewujudkan Nasionalisme. CIVIS, $1(1 /$ Januari).

Zabda, S. (2017). Aktualisasi Nilai-nilai Pancasila sebagai Dasar Falsafah Negara dan Implementasinya Dalam Pembangunan Karater Bangsa. Jurnal Pendidikan Ilmu Sosial, 26(2), 106-114. 